\title{
Chromosomes and Repetitive DNAs: A Contribution to the Knowledge of the Fish Genome
}

\author{
Cesar Martins
}

\section{INTRODUCTION}

Primary studies on whole sequenced genomes focused on single genes and little attention was directed to repetitive DNAs, and duplicated segments. Single- and few-copy sequences correspond to a small fraction of the genomes. For example, only $1.5 \%$ of the human genome is composed of coding sequences (Horvath et al., 2001). On the other hand, the eukaryote genome contains several types of DNA sequences present in multiple copies that, in some instances, can represent large portions of the genome (Charlesworth et al., 1994). Although extensively studied for the past three decades, the molecular forces that propagate and maintain repetitive DNAs in the genome are still being discussed.

Address for Correspondence: UNESP - Universidade Estadual Paulista, Instituto de Biociências, Departamento de Morfologia, CEP 18618-000, Botucatu, SP, Brazil.

E-mail: cmartins@ibb.unesp.br 
Repeated DNA elements are often considered to be 'selfish' DNA (Doolittle and Sapienza, 1980; Orgel and Crick, 1980) or 'junk DNA' (Nowak, 1994) in the genome and they make no biological contributions to the carriers. Although the repetitive DNA sequences were thought to be functionless, their involvement in some diseases (Kazazian et al., 1988), gene regulation and repair (Messier et al., 1996), as well as in sex chromosome differentiation (Anleitner and Haymer, 1992; Kraemer and Schmidt, 1993) has been suggested. The repetitive sequence importance in gene regulation and chromosome physiology may be illustrated by mutations in some minisatellite sequences that may contribute to as many as $10 \%$ of all cases of breast, colorectal and bladder cancer, and acute leukemia (Devlin et al., 1993). The most significant function for the repetitive sequences is related to the head-to-tail tandem repeats of the centromere and telomere of eukaryote chromosomes. Centromeres, the primary constriction of each metaphase eukaryotic chromosome, are critical to the proper sorting of chromosomes during cell division; if it does not work correctly, it can result in cancer, defects in developmental, or similar misfortunes. Telomeres, the end of linear eukaryotic chromosomes, also play a critical role in maintaining chromosomal stability and function. Taken together, these data show that repeated DNAs seem to have an important role in the genome organization and evolution, leading to a significant impact on the speciation process.

In many species, repeated sequences comprise a large portion of the genomes. Ninety-five percent of the onion genome (Flavell et al., 1974) and $50 \%$ or much more of the human genome corresponds to repeated sequences (The Genome International Sequencing Consortium, 2001). The first question that arises is: what is the reason for the large number of repeated DNAs in the genome? During the course of eukaryotic evolution, genes and genome segments seem to have duplicated, leading to an increase of the DNA content in the cell nucleus. The variation in genome size of different eukaryotes is often reported as differences in the amount of repeated DNA sequences (Cavalier-Smith, 1985; Brenner et al., 1993). Recently, advances in studies concerning non-coding repetitive DNA sequences have shown that such sequences are extremely important in the structural and functional organization of the genome (Schueler et al., 2001).

Repetitive DNAs include the tandemly-arrayed satellite, minisatellite and microsatellite sequences, and dispersed repeats such as transposons 
and retrotransposons (Charlesworth et al., 1994). Some large satellite DNAs, often called macrosatellite DNA, have also been reported (Takahashi et al., 1994). There are also multigene families composed of hundreds to thousands of copies that code important molecules such as the ribosomal RNAs (rRNA), for example. The most known non-coding repetitive sequences are the head-to-tail tandem-arrayed repetitions found in the centromeres and telomeres. Most repetitive sequences are known to be highly unstable in the genomes (Charlesworth et al., 1994). The magnitude of genome instability due to head-to-tail tandem repeats is often much higher than that due to transposons (Gondo et al., 1998). These repetitive DNA sequences are thought to arise by many mechanisms, from direct sequence amplification by unequal recombination of homologous DNA regions to the reverse flow of genetic information using an intermediate RNA molecule. Due to the hypervariability of the tandem repeats, such genome segments are highly polymorphic and considered to be good molecular markers for genotyping of individuals and populations (Jeffreys et al., 1985).

A general overview of the human genome, for instance, shows that the majority of genes are located in an interstitial chromosome position far away from the centromere and telomere heterochromatins (Horvath et al., 2001). On the other hand, the repetitive rich chromosome regions are poorly understood. Among entire sequenced genomes, the repetitive areas remain as gaps because of the difficulty in determining their correct positioning and array in the genome. Even chromosomes reportedly 'sequenced to completion' such as chromosome 22 of humans have multiple gaps in the pericentromeric regions (Dunham et al., 1999). A complete understanding of the relationship between chromosome structure and function requires the repetitive segments to be fully resolved.

Studies of the repetitive fraction of the genome can contribute to the knowledge of the complex organization of DNA in the cell nucleus. Also, the integration of DNA sequences with chromosome mapping of repetitive DNAs can provide a better landscape of the genome, which is not yet clearly defined even in the wholly sequenced genomes. The repetitive DNA sequences can also provide chromosome markers useful in studies of species evolution, identification of specific chromosomes, homologous chromosomes, chromosome rearrangements, sex 
chromosomes, and applied genetics. In this chapter, I will focus on the understanding of the structure of the fish genome based on the repetitive sequences and their organization in the chromosomes.

\section{Tandem Repeats and Dispersed Elements}

\section{Satellite DNAs}

Although in the last two decades cytogenetic studies have been carried out in a large number of fish species, such analyses were mainly directed to the knowledge of basic karyotype structure and few research works have been conducted in the field of organization of DNA sequences in the chromosomes. Concerning chromosomal organization of repetitive DNA sequences, one of the most studied fractions of the fish genome is the satellite DNA. Satellite DNAs are tandemly arrayed, highly repetitive DNA sequences found in the eukaryotic genomes. These sequences can vary from 1,000 to over 100,000 copies of a basic motif or repeat unit, commonly 100-300 base pairs (bp), which occur at a few loci on the genome. These sequences are organized as large clusters mainly in the centromeric and telomeric regions of the chromosomes, and are the principal component of heterochromatins. Satellite DNA families can correspond to $0-66 \%$ of certain mammalian genomes and their composition and number of unrelated families can vary greatly (Beridze, 1986). Different species generally present a divergence among satellite DNA families as a result of concerted evolution mechanisms (Arnheim, 1983), leading to species-specific satellite DNA sequences. On the other hand, there are a few exceptions in which a group of species, or even a whole family or order, shares the same satellite DNA family. The most interesting example is the centromeric alpha satellite DNA that is preserved in the primate order, most probably because of its centromeric function (Schueler et al., 2001). Alpha satellite-like sequences were also detected in the chicken and zebrafish, showing an interesting sequence identity with human alpha sequences ( $\mathrm{Li}$ and Kirby, 2003).

Satellite DNAs are useful for molecular cytogenetic analysis such as the identification of homologous chromosomes and chromosomal abnormalities by in situ hybridization. The molecular organization, chromosomal location, and possible functions of satellite DNAs have been studied in several groups of animals (Brutlag, 1980; Singer, 1982; Arnason et al., 1984; Hummel et al., 1984; Clabby et al., 1996). These studies have 
indicated the fact that satellite-like sequences may play an important role at the chromosomal and nuclear level (Singer, 1982; Haaf and Schmid, 1991; Larin et al., 1994; Sart et al., 1997).

Although the chromosome distribution of the heterochromatinwhere the satellite DNAs are supposed to be concentrated-has been extensively studied in fishes using cytological methods of staining or chromosome banding, molecular data on satellite DNAs are restricted to a few species (Table 4.4.1). The first descriptions of satellite DNA families in fishes correspond to the end of the 1980s (Datta et al., 1988; Moyer et al., 1988; Monaco et al., 1989). The data on satellite DNAs in fishes show that these sequences are mainly located in the centromeric region of chromosomes (Table 4.4.1). A HindIII satellite DNA family isolated from the sturgeon Acipenser naccarii genome was preserved in the pericentromeric regions of the chromosomes of six species of the genus Acipenser and one of the genus Huso (Lanfredi et al., 2001). Centromeric satellite DNA families were also isolated from the genome of the gobiid Gobius cobitis (Canapa et al., 2002) and the Nile tilapia Oreochromis niloticus (Franck and Wright, 1993). Particularly in the Nile tilapia, the satellite family was present in the centromeres of all chromosomes of the complement (Oliveira and Wright 1998) (Fig. 4.4.1a, b). The tilapia satellite was also preserved in the genome of other tilapiine and haplochromine species (Franck et al., 1994), thus leading to the possible hypothesis that this satellite sequence originated in an ancestor of the group, and subsequently, has been maintained in the centromeres of all chromosomes due to its functionality. One interesting feature of most centromeric satellite repeats is their basic length unit (155-180 bp) corresponding to the range of nucleosomal unit lengths (Henikoff et al., 2001). Larger repeat lengths may encompass two nucleosomes. An extensive analysis of centromeric satellite DNAs of vertebrates showed the presence of short A-rich motifs that are typical of centromere satellite (Vinãs et al., 2004). Short A-rich motifs have been identified in the centromeric satellite DNAs of various fish species (Wright, 1989; Denovan and Wright, 1990; Garrido-Ramos et al., 1994, 1995; Kato, 1999; Canapa et al., 2002; Viñas et al., 2004). These short sequences are quite similar and show considerable homology to other centromeric motifs found in humans (Vissel et al., 1992), mice (Wong and Rattner, 1988), and reptiles (Cremisi et al., 1988), suggesting that such sequences might also play some important role in the structure and function of the fish centromere. 
Table 4.4.1 DNA tandem repeats and their chromosomal distribution in fishes.

\begin{tabular}{|c|c|c|c|}
\hline Fish families and species & $\begin{array}{l}\text { Repeat size } \\
\quad(b p)\end{array}$ & $\begin{array}{l}\text { Chromosome } \\
\text { position }\end{array}$ & References \\
\hline \multicolumn{4}{|l|}{ Acipenseridae } \\
\hline Acipenser naccarii & 180 & centromeric & $\begin{array}{l}\text { Garrido-Ramos et al., 1997; } \\
\text { Lanfredi et al., } 2001\end{array}$ \\
\hline Acipenser gueldenstaedtii & 180 & centromeric & Lanfredi et al., 2001 \\
\hline Acipenser baerii & 180 & centromeric & Lanfredi et al., 2001 \\
\hline Acipenser transmontanus & 180 & centromeric & Lanfredi et al., 2001 \\
\hline Acipenser ruthenus & 180 & centromeric & Lanfredi et al., 2001 \\
\hline Huso huso & 180 & centromeric & Lanfredi et al., 2001 \\
\hline \multicolumn{4}{|l|}{ Adrianichthyidae } \\
\hline $\begin{array}{l}\text { Anostomidae } \\
\text { Leporinus elongatus } \\
\text { Leporinus obtusidens }\end{array}$ & $\begin{array}{c}174,729 \\
483\end{array}$ & $\begin{array}{l}\text { chromosomes } \mathrm{Z} \text { and } \mathrm{W} \\
\text { pericentromeric }\end{array}$ & $\begin{array}{l}\text { Nakayama et al., } 1994 \\
\text { Koehler et al., } 1997\end{array}$ \\
\hline \multicolumn{2}{|l|}{ Channichthydae } & centromeric and telomeric & Capriglione et al., 1994 \\
\hline $\begin{array}{l}\text { Characidae } \\
\text { Astyanax scabripinnis }\end{array}$ & 51 & heterochromatins & $\begin{array}{l}\text { Mestriner et al., 2000; } \\
\text { Mantovani et al., } 2004\end{array}$ \\
\hline $\begin{array}{l}\text { Cichlidae } \\
\text { Oreochromis niloticus }\end{array}$ & 237 & centromeric & $\begin{array}{l}\text { Franck et al., 1992; } \\
\text { Oliveira and Wright, } 1998\end{array}$ \\
\hline Oreochromis niloticus & 1,900 & $\begin{array}{l}\text { short arm of chromosome } \\
\text { four }\end{array}$ & $\begin{array}{l}\text { Frank and Wright, 1993; } \\
\text { Oliveira and Wright, } 1998\end{array}$ \\
\hline \multicolumn{4}{|l|}{ Cyprinidae } \\
\hline Carassius auratus langsdorfi & 137 & & $\begin{array}{l}\text { Murakami and Fujitani, } \\
1997\end{array}$ \\
\hline Danio rerio & 180,191 & centromeric & $\begin{array}{l}\text { Ekker et al., 1992; He et al., } \\
\text { 1992; Sola and Gornung, } \\
2001\end{array}$ \\
\hline Danio rerio & 200 & AT-rich heterochromatins & Phillips and Reed, 2000 \\
\hline Danio rerio & 92 & GC-rich heterochromatins & Phillips and Reed, 2000 \\
\hline \multicolumn{4}{|l|}{ Erythrinidae } \\
\hline Hoplias malabaricus & $333-366$ & centromeric & Haaf et al., 1993 \\
\hline Hoplias malabaricus & $356-360$ & centromeric & Martins et al.,(submitted) \\
\hline \multicolumn{4}{|l|}{ Gobiidae } \\
\hline Gobius cobitis & 332 & centromeric & Canapa et al., 2002 \\
\hline Gobius paganellus & 332 & centromeric & Canapa et al., 2002 \\
\hline
\end{tabular}


Cesar Martins

(Table 4.4.1 contd.)

\begin{tabular}{|c|c|c|c|}
\hline $\begin{array}{l}\text { Heptapteridae } \\
\text { Imparfinis schubarti }\end{array}$ & 2 & telomeric & Vanzela et al., 2002 \\
\hline $\begin{array}{l}\text { Loricariidae } \\
\text { Rineloricaria latirostris }\end{array}$ & 2 & near NOR & Vanzela et al., 2002 \\
\hline $\begin{array}{l}\text { Parodontidae } \\
\text { Parodon hilarii }\end{array}$ & 200 & $\begin{array}{l}\text { terminal heterochromatins, } \\
\mathrm{s}, \mathrm{W} \text { chromosome }\end{array}$ & Vicente et al., 2003 \\
\hline $\begin{array}{l}\text { Pimelodidae } \\
\text { Steindachneridion scripta }\end{array}$ & 2 & telomeric, dispersed & Vanzela et al., 2002 \\
\hline $\begin{array}{l}\text { Poecilidae } \\
\text { Poecilia reticulata }\end{array}$ & 4 & Y chromosome & Nanda et al., 1990 \\
\hline $\begin{array}{l}\text { Prochilodontidae } \\
\text { Prochilodus lineatus } \\
\text { Prochilodus lineatus } \\
\text { Prochilodus lineatus } \\
\text { Prochilodus marggravii }\end{array}$ & $\begin{array}{l}441 \\
900 \\
5 \\
5\end{array}$ & $\begin{array}{l}\text { pericentromeric } \\
\text { pericentromeric and } \\
\text { supernumeraries } \\
\text { telomeric } \\
\text { telomeric }\end{array}$ & $\begin{array}{l}\text { Jesus et al., } 2003 \\
\text { Jesus et al., } 2003 \\
\text { Hatanaka et al., } 2002 \\
\text { Hatanaka et al., } 2002\end{array}$ \\
\hline $\begin{array}{l}\text { Salmonidae } \\
\text { Salvelinus alpinus }\end{array}$ & $\begin{array}{l}72,127 \\
200,400\end{array}$ & centromeric & $\begin{array}{l}\text { Hartley and Davidson, } \\
1994\end{array}$ \\
\hline $\begin{array}{l}\text { Salvelinus namaycush } \\
\text { Salvelinus namaycush } \\
\text { Salmo trutta }\end{array}$ & $\begin{array}{l}140 \\
120 \\
359\end{array}$ & $\begin{array}{l}\text { centromeric } \\
\text { centromeric } \\
\text { NOR }\end{array}$ & $\begin{array}{l}\text { Reed and Phillips, } 1995 \\
\text { Reed and Phillips, } 1995 \\
\text { Abuín et al., } 1996\end{array}$ \\
\hline Salmo salar & $\begin{array}{c}380,442 \\
923\end{array}$ & NOR, rDNA & $\begin{array}{l}\text { Goodier and Davidson, } \\
\text { 1994; Abuín et al., } 1996\end{array}$ \\
\hline $\begin{array}{l}\text { Salmo salar } \\
\text { Salmo salar } \\
\text { Salmo salar }\end{array}$ & $\begin{array}{l}260 \\
42 \\
28\end{array}$ & $\begin{array}{l}\text { pericentromeric } \\
\text { interstitial } \\
\text { telomeric, pericentromeric, } \\
\text { centromeric }\end{array}$ & $\begin{array}{l}\text { Pérez et al., } 1999 \\
\text { Pérez et al., } 1999\end{array}$ \\
\hline $\begin{array}{l}\text { Salmo salar } \\
\text { Oncorhynchus tshawytscha }\end{array}$ & $\begin{array}{c}34 \\
939\end{array}$ & $\begin{array}{l}\text { interstitial } \\
\text { subtelomeric }\end{array}$ & $\begin{array}{l}\text { Pérez et al., } 1999 \\
\text { Devlin et al. 1991, } 1998\end{array}$ \\
\hline $\begin{array}{l}\text { Sparidae } \\
\text { Sparus aurata } \\
\text { Pagrus pagrus } \\
\text { Pagrus aurica } \\
\text { Pagellus erythrinus }\end{array}$ & $\begin{array}{l}186 \\
186 \\
186 \\
186\end{array}$ & $\begin{array}{l}\text { centromeric } \\
\text { subtelomeric } \\
\text { subtelomeric } \\
\text { subtelomeric and telomeric }\end{array}$ & $\begin{array}{l}\text { Garrido-Ramos et al., } 1994 \\
\text { Garrido-Ramos et al., } 1998 \\
\text { Garrido-Ramos et al., } 1998 \\
\text { Garrido-Ramos et al., } 1998\end{array}$ \\
\hline $\begin{array}{l}\text { Tetraodontidae } \\
\text { Tetraodon nigroviridis } \\
\text { Tetraodon nigroviridis }\end{array}$ & $\begin{array}{c}118 \\
10\end{array}$ & $\begin{array}{l}\text { (peri)centromeric } \\
\text { heterochromatins }\end{array}$ & $\begin{array}{l}\text { Crollius et al., } 2000 \\
\text { Crollius et al., } 2000\end{array}$ \\
\hline
\end{tabular}

(Table 4.4 .1 contd.) 
(Table 4.4 .1 contd.)

\begin{tabular}{l|c|l|l}
\hline Tetraodon nigroviridis & 100 & heterochromatins & Fischer et al., 2004 \\
\hline $\begin{array}{l}\text { Tetraodon nigroviridis } \\
\text { Fugu rubripes }\end{array}$ & 104 & heterochromatins & Fischer et al., 2004 \\
Cyclostomata & 118 & $\begin{array}{l}\text { Brenner et al., 1993; } \\
\text { Elgar et al., 1999 }\end{array}$ \\
$\begin{array}{l}\text { Eptatretus okinoseanus } \\
\text { Eptatretus burgeri } \\
\text { Petromyzon marinus }\end{array}$ & 57 and 64 & $\begin{array}{l}\text { interstitial } \\
\text { interstitial } \\
\text { centromeric and } \\
\text { pericentromeric }\end{array}$ & $\begin{array}{l}\text { Kubota et al., } 1993 \\
\text { Kubota et al., 2001 } \\
\text { Bóan et al., 1996 }\end{array}$ \\
\hline
\end{tabular}
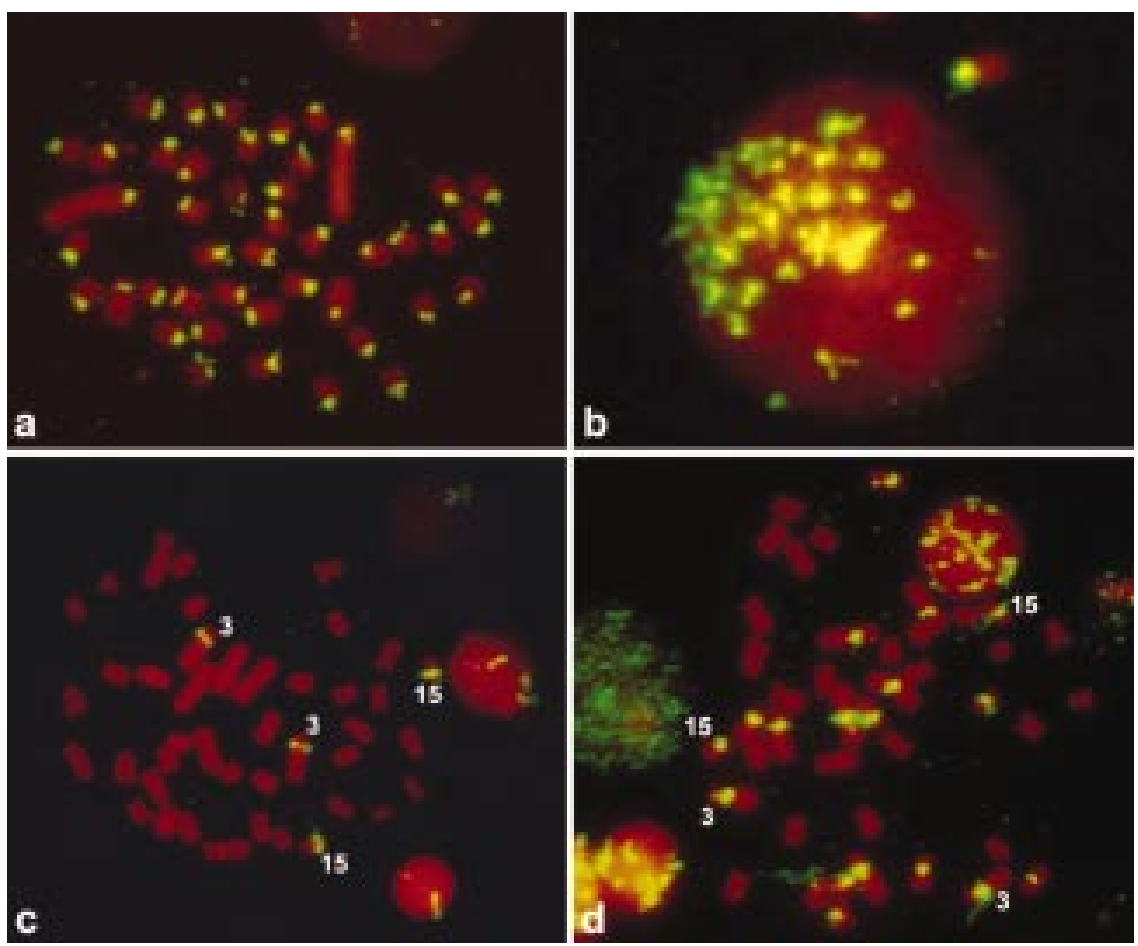

Fig. 4.4.1 Fluorescence in situ hybridization of SATA satellite DNA family in the chromosomes (a) and in the interphasic nucleous (b) of Oreochromis niloticus. The SATA maps into the centromeres of all chromosomes and has a non-random distribution in the interphasic nucleous. Fluorescence in situ hybridization of the true-5S rDNA (c) and variant-5S rDNA (d) repeats in the chromosomes of $H$. malabaricus, under highly stringent conditions. The chromosome pairs number 3 and 15 are indicated. (Courtesy of Irani A. Ferreira). 
Particular attention has been directed to the identification of satellite DNAs related to sex and supernumerary chromosomes in fishes. Satellite DNAs have been isolated and mapped in sex chromosomes of several species, such as Leporinus elongatus (Nakayama et al., 1994), Chiondraco hamatus (Capriglione et al., 1994), Poecilia reticulata (Nanda et al., 1990), and Oncorhynchus tschawytscha (Devlin et al., 1991; Stein et al., 2001), among others.

Morphologically differentiated sex chromosomes occur in several fish species. The South American fishes of the genus Leporinus (Anostomidae, Characiformes) represent a good model for studying sex chromosome differentiation. A clear ZZ/ZW sex chromosome system has been described for seven out of 40 studied species (L. conirostris, L. trifasciatus, L. obtusidens, L. elongatus, L. macrocephalus, L. reinhardti and L. aff. elongatus) (Galetti et al., 1995). In these species, the subtelocentric W chromosome, only present in the female karyotype, is large and almost fully heterochromatic. In contrast, the $\mathrm{Z}$ chromosome, which is present in both sexes, is heterochromatic on the distal third part of the long arm. The shared morphological features of chromosomes Z and W among these seven ZW Leporinus suggest a common origin (Galetti et al., 1995) and an initial heterochromatinization could have been the first step in the differentiation of these sex chromosomes (Galetti and Foresti, 1986). On the other hand, a novel ZW chromosome system, morphologically differentiated from the ZZ/ZW system previously detected, was described for Leporinus sp2 (Venere et al., 2004).

Two satellite DNA families were isolated from Leporinus elongatus by subtractive hybridization and cloning (Nakayama et al., 1994). One of them was located in both $\mathrm{Z}$ and $\mathrm{W}$ chromosomes, whereas the second family was specific to the $\mathrm{W}$ chromosome, which permits the sex identification of individuals of the species. Three atypical individuals, one ZW female, recognized as male with the W-specific probe sequence, and two ZW males, one of them showing satellite-pattern of males, were detected in the analysis. These three individuals seem to have originated from genetic exchange between regions of the chromosomes $\mathrm{Z}$ and $\mathrm{W}$, yielding the atypical patterns observed. These data on sex chromosome in Leporinus allowed the construction of a model for the W chromosome differentiation that offers important contributions to the knowledge of sex-determination mechanisms in fishes. 
Among salmonids, extensive studies have been conducted with the purpose of isolating DNA sequences to be used as markers for sex identification, since the heteromorphism of the $\mathrm{X}$ and $\mathrm{Y}$ chromosomes is not easily detected. An Y-specific repetitive DNA sequence with 300 copies organized in approximately six distinct clusters was isolated from the genome of the salmon Oncorhynchus tshawytscha (Devlin et al., 1991, 1998; Stein et al., 2001). Contrary to what was observed in several eukaryotes where long repetitive sequences originated from the duplication of short repeat units, the $8 \mathrm{~kb}$ repeat isolated from salmon does not contain relics of internal short repeats.

Another interesting issue is the presence of supernumerary chromosomes that have been described in case of several fish species. A satellite DNA correlated to a supernumerary chromosome was firstly isolated in Astyanax scabripinnis, a small headwater fish that has become a model species not only because of numeric and structural chromosome variations but also due to the occurrence of supernumerary chromosomes. In this species, the isolated repetitive DNA family, named As51, had repeats of $51 \mathrm{bp}$ and was located in the non-centromeric heterochromatins, in the NORs and in the supernumerary chromosome. Interestingly, the As51 satellite family showed $58.8 \%$ similarity with a segment of the retrotransposon RT2 of Anopheles gambiae and a lower similarity with the transposase gene of the transposon TN4430 of Bacillus thuringiensis, suggesting that this sequence might have arisen from a mobile element. The presence of As51 satellite in the NOR region suggests that this repetitive family can be interspersed in the spacers of the $45 \mathrm{~S}$ rDNA - being inserted in this region by transposition-as described before for other organisms. Although the chromosome hybridization detected fluorescent signals in almost the whole extension of the supernumerary chromosome, it was possible to verify that the satellite DNA As51 is organized in small clusters interspersed with other DNA types. The symmetric distribution in both arms of the supernumerary chromosome of A. scabripinnins and its meiotic behavior suggest that this chromosome is an isochromosome (Mestriner et al., 2000).

Analyses of the nucleotide composition of supernumerary chromosome of other species showed that they are mainly composed of repetitive DNAs. Such data is related to the heterochromatic nature of the supernumeraries. 
Satellite DNAs were also isolated from Prochilodus lineatus, which presents from zero to five small supernumerary chromosomes (Pauls and Bertollo, 1983). Two satellite DNA families, with monomeric units of 441 and $900 \mathrm{bp}$, were isolated from the genome of this species (Jesus et al., 2003). Both satellite families were located in the pericentromeric region of several chromosomes of the A complement and the 900 bp satellite was also located in several supernumeraries. Double-chromosome hybridization using the 441- and the 900-bp satellites as probes showed that both families co-localize in the pericentromeric region of some chromosomes. Several sub repeats were detected in the 900-bp satellite, suggesting its origin from small repeat units. Such results demonstrate that the supernumerary chromosomes of this species have originated from A chromosomes that harbor the 900-bp satellite DNA family (Jesus et al., 2003).

Studies on satellite DNAs have proved useful in clarifying a myriad of questions, including centromeric structure, and origin and evolution of sex and supernumerary chromosomes. Satellite DNAs could also find applications in the physical mapping of the genome, contributing to the development of genetic markers of significant importance to fundamental and applied biology of fish species.

\section{Minisatellite DNAs}

The definition of a minisatellite repeat is not particularly well standardized. Minisatellite includes all tandem repeats that are not sufficiently large to be included as a satellite repeat nor small enough to be considered a microsatellite sequence. Most scientists consider minisatellite to be tandem arrays (5-50 repeats) of moderately repetitive short DNA sequences (10-60 bases) found dispersed throughout the genome and clustered near telomeres. The intense evolutionary dynamics of minisatellites generate complex arrays of such sequences in the genome that can be used as specific markers for an individual. Microsatellites were first used in forensic applications and in paternity assessment in humans (Jeffreys et al., 1985) and were later widely applied to population and identification of organisms from bacteria to mammals. Although minisatellites have been described for many fish species (Goodier and Davidon, 1998), the chromosomal mapping of minisatellites was only described for a few species (Table 4.4.1). In the Atlantic salmon (Salmo 
salar) (Pérez et al., 1999), three minisatellites with core sequences of 42 , 28 and 34 nucleotides were mapped onto the chromosomes. A single locus was detected for the 42-mer and 34-mer microsatellites and a multilocus pattern was detected for the 28-mer microsatellite. Analyses of the pufferfish (Tetraodon nigroviridis) genome allowed the identification of two major classes of tandem repeat elements: one corresponding to a 118-mer satellite that was mapped in the centromeric region of all chromosomes and the other with 10-mer minisatellite that was mapped in the complete length of the short arm of 10 subtelocentric chromosomes (Crollius et al., 2000).

\section{Microsatellite DNAs}

Microsatellites consist of tandem repeats sequences of short DNA sequences with one to five or six bases interspersed in the eukaryotes genome (Tautz and Renz, 1984). The tandem array of the microsatellites are usually less than 100 bases long and have been used for linkage map analysis. A linkage map analyses of the zebrafish Danio rerio genome using 200 microsatellite markers of the CA and GT types identified that the $(\mathrm{CA})_{\mathrm{n}}$ and $(\mathrm{GT})_{\mathrm{n}}$ repeats are more clustered in the centromeric and telomeric regions (Shimoda et al., 1999). Clustering of microsatellites in the centromeres and telomeres was also detected by in situ chromosome mapping. In three species of the genus Prochilodus (Prochilodontidae, Characiformes), the $(\text { AATTT })_{n}$ repeats revealed 13 alleles while chromosome mapping showed signals predominantly in the telomeric regions of several chromosomes (Hatanaka et al., 2002). (GA) microsatellite repeats were highly clustered in the telomeric regions of Imparfinis schubarti (Heptapteridae, Siluriformes), dispersed along the chromosome arms with enhanced signals in some telomeric regions in Steindachneridion scripta (Pimelodidae, Siluriformes), and near to the NOR sites in Rineloricaria latirostris (Loricariidae, Siluriformes) (Vanzela et al., 2002). In situ chromosome hybridization detected rich segments of the $(\mathrm{GACA})_{\mathrm{n}}$ repetitive sequence in the heterochromatic portion of the $\mathrm{W}$ and Y chromosomes of Poecilia reticulata (Poecilidae, Cyprinodontiformes) (Nanda et al., 1990). The microsatellites are essentially located in the heterochromatic regions (telomeres, centromeres and sex chromosomes) of fish genome, where a significant fraction of the repetitive DNAs is believed to be localized. 